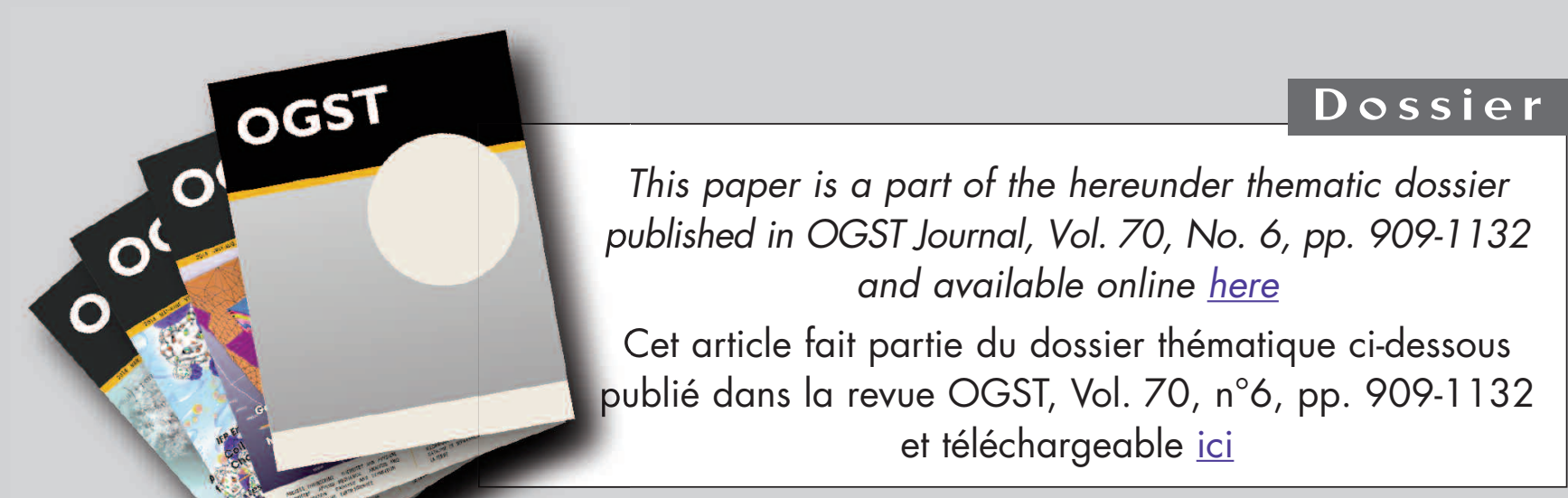

Oil \& Gas Science and Technology - Rev. IFP Energies nouvelles, Vol. 70 (2015), No. 6, pp. 909-1132

Copyright (C) 2015, IFP Energies nouvelles

909 > Editorial - Enhanced Oil Recovery (EOR), Asphaltenes and Hydrates Éditorial - EOR «récupération assistée du pétrole», Asphaltènes et Hydrates D. Langevin and F. Baudin

\section{ENHANCED OIL RECOVERY (EOR)}

917 > HP-HT Drilling Mud Based on Environmently-Friendly Fluorinated Chemicals Boues de forage HP/HT à base de composés fluorés respectueux de I'environnement

I. Henaut, D. Pasquier, S. Rovinetti and B. Espagne

931 > Effective Viscosity in Porous Media and Applicable Limitations for Polymer Flooding of an Associative Polymer

Viscosité effective dans des médias poreux et limites d'application de l'injection de polymères associatifs

P. Zhang, Y. Wang, Y. Yang, W. Chen and S. Bai

$941>$ Dynamic Gelation of HPAM/Cr(III) under Shear in an Agitator and Porous Media Gélification dynamique de HPAM/Cr(III) sous cisaillement dans un agitateur et en milieu poreux

Y. Haiyang, W. Yefei, Z. Jian, L. Peng and S. Shenglong

$951>$ Computer Modeling of the Displacement Behavior of Carbon Dioxide in Undersaturated Oil Reservoirs

Modélisation par ordinateur du comportement de déplacement du dioxyde de carbone dans des réservoirs d'huile non saturés

B. Ju, Y.S. Wu and J. Qin

$967>$ Predicting CO, Minimum Miscibility Pressure (MMP) Using Alternating Conditional Expectation (ACE) Algorithm

Prédiction de la pression miscibilité minimum (MMP) du CO en utilisant un algorithme basé sur l'ACE (Alternating Conditional Expectation)

0 . Alomair, A. Malallah, A. Elsharkawy and M. Iqbal

983 > Towards the Development of Bitumen Carbonates: An Integrated Analysis of Grosmont Steam Pilots

Vers le développement des carbonates bitumineux : une analyse intégrée des pilotes vapeur de Grosmont

C.C. Ezeuko, J. Wang, M.S. Kallos and I.D. Gates

1007> A Novel Model of Foam Flooding Considering Multi-Factors for Enhancing Oil Recovery

Un nouveau modèle d'injection de mousse considérant de multiples facteurs afin d'améliorer la récupération de pétrole

J. Wang, H. Liu, H. Zhang, G. Zhang, P. Liu and K. Sepehrnoori
1025> Testing of Snorre Field Foam Assisted Water Alternating Gas (FAWAG) Performance in New Foam Screening Model

Vérification des performances de la méthode FAWAG (Foam Assisted Water Alternating Gas) sur le champ de Snorre, en Norvège, avec un nouveau modèle de sélection des mousses

P. Spirov and S. Rudyk

\section{ASPHALTENES}

1035> Structural Study of Asphaltenes from Iranian Heavy Crude Oil Étude structurale d'asphaltènes de pétrole brut lourd iranien L. Davarpanah, F. Vahabzadeh and A. Dermanaki

$1051>$ Experimental Study and Mathematical Modeling of Asphaltene Deposition Mechanism in Core Samples

Étude expérimentale et modélisation mathématique du mécanisme de déposition d'asphaltène dans des carottes de forage

T. Jafari Behbahani, C. Ghotbi, V. Taghikhani and A. Shahrabadi

1075> Prediction of the Gas Injection Effect on the Asphaltene Phase Envelope Prévision Prévision de l'effet d'injection de gaz sur l'enveloppe de phase des asphaltènes P. Bahrami, R. Kharrat, S. Mahdavi and H. Firoozinia

\section{HYDRATES}

1087> Methane Hydrate Formation and Dissociation in the Presence of Silica Sand and Bentonite Clay

Formation et dissociation d'hydrates de méthane en présence de sable de silice et d'argile de bentonite

V. Kumar Saw, G. Udayabhanu, A. Mandal and S. Laik

$1101>$ Prediction of Mass Flow Rate in Supersonic Natural Gas Processing Prédiction du débit massique dans les applications de traitement supersonique du gaz naturel

C. Wen, X. Cao, Y. Yang and Y. Feng

$1111>$ Experimental Study on Hydrate Induction Time of Gas-Saturated Water-in-Oil Emulsion using a High-Pressure Flow Loop

Étude expérimentale sur le temps d'induction d'hydrate d'une émulsion eau-enhuile saturée en gaz en utilisant une boucle à circulation sous haute pression X.F. Lv, B.H. Shi, Y. Wang, Y.X. Tang, L.Y. Wang and J. Gong

1125> Hollow Silica: A Novel Material for Methane Storage La silice creuse : un nouveau matériau pour le stockage de méthane V.D. Chari, P.S.R. Prasad and S.R. Murthy 


\title{
Editorial
}

\author{
Dominique Langevin ${ }^{1}$ and François Baudin ${ }^{2}$ \\ 1 Université Paris 11, Laboratoire de Physiques des Solides, UMR 8502, 91405 Orsay - France \\ 2 Université de Paris 06, Institut des Sciences de la Terre de Paris, UMR 7193, 75005 Paris - France
}

The $6^{\text {th }}$ issue of OGST in 2015 collects individual contributions, at the difference of the other issues, dedicated to particular topics or to the proceedings of conferences held in IFP Energies nouvelles (IFPEN). The contributions to this issue have been classified into three groups: Enhanced Oil Recovery (EOR), asphaltenes and hydrates. EOR has been the topic of a special issue in 2012: Challenges and New Approaches in EOR. The corresponding editorial described the historical perspective in detail (Langevin and Combarnous, 2012). We will just recall here that after a very active period following the oil shock in 1973 and a less active period around 2000 when the oil price went low, active research started again in the recent years. Because heavy crude oils and bitumen are an important fraction of the present reserves, part of the new research is devoted to the specific problems caused by these extremely viscous oils.

Asphaltenes were also the object of a considerable research work since many years (Speight, 2004). They are the oil components of larger polarity and molecular weight. If the oil contains appreciable amounts of non-polar light components, asphaltene precipitation may occur, causing damages. When asphaltene amounts are high, the oil is very viscous, leading to extraction and transportation problems. Asphaltenes being more polar than the other oil components have a tendency to adsorb at surfaces, a field also much investigated in relation to wettability of reservoir rock and stability of emulsions formed in the presence of water. Despite years of research, our knowledge on asphaltenes is still limited. This is largely due to the fact that they are a mixture of many different species, the species depending on the extraction method for a given oil. In addition, asphaltenes have a tendency to aggregate, making even the determination of their molecular weight difficult. Many debates about asphaltene behavior occurred over the years, and controversies are still quite active.

Gas hydrates are ice-like substances, in which the molecules of gas are trapped inside "cages" of hydrogen-bonded frozen water molecules, naturally occurring when these components are present at a low temperature and a high pressure. Such conditions often exist in sedimentary column of continental margins, in the permafrost, oil and gas wells, and pipeline equipment. Their detailed formation and decomposition mechanisms on a molecular level, which are first order phase transitions not chemical reactions, are still not well understood. The research on hydrates is presently quite active and aims to optimize their recovery and to better predict plugging accidents (Makogon, 2010).

We will now present briefly the content of the different papers, starting with the EOR group. "HP-HT Drilling Mud Based on Environmently-Friendly Fluorinated Chemicals" by I. Henaut, D. Pasquier, S. Rovinetti and B. Espagne. This paper describes new formulations 
for drilling muds based on perfluorinated compounds, able to function at high temperature and pressure (Henaut et al., 2015).

"Effective Viscosity in Porous Media and Applicable Limitations for Polymer Flooding of an Associative Polymer" by P. Zhang, Y. Wang, Y. Yang, W. Chen and S. Bai. In this paper, the superiority of a hydrophobically modified polyacrylamide over the unmodified polyacrylamide for water thickening is demonstrated. The efficacy of the two types of polymers during oil displacement in porous media is also compared. The modified polymer is shown to be an interesting candidate for EOR (Zhang et al., 2015).

"Dynamic Gelation of HPAM/Cr(III) under Shear in an Agitator and Porous Media" by Y. Haiyang, W. Yefei, Z. Jian, L. Peng and S. Shenglong. This paper investigates the gelation behavior of a polymer currently used in EOR for water thickening. The experiments made in standard bottles and in porous media were compared, both at rest and under flow. It was found that the gelation times are much longer in porous media (Haiyang et al., 2015).

"Computer Modeling of the Displacement Behavior of Carbon Dioxide in Undersaturated Oil Reservoirs" by B. Ju, Y.-S. Wu and J. Qin. This new model allows the prediction of $\mathrm{CO}_{2}$ flow in oil reservoirs, for both miscible and non-miscible flows. The model was validated with experimental data (Ju et al., 2015).

"Predicting $\mathrm{CO}_{2}$ Minimum Miscibility Pressure (MMP) Using Alternating Conditional Expectation (ACE) Algorithm" by O. Alomair, A. Malallah, A. Elsharkawy and M. Iqbal. This new model was shown to be able to predict the minimum miscibility pressure for pure $\mathrm{CO}_{2}$ measured for more than 100 different oils. The model has no adjustable parameters and is based only on experimental data (Alomair et al., 2015).

"Towards the Development of Bitumen Carbonates: An Integrated Analysis of Grosmont Steam Pilots" by C.C. Ezeuko, J. Wang, M.S. Kallos and I.D. Gates. This paper describes steam pilots trials in a Canadian bitumen-rich carbonate reservoir. A particular method (cyclic steam simulation) is recommended for the exploitation of this reservoir (Ezeuko et al., 2015).

"A Novel Model of Foam Flooding Considering Multi-Factors for Enhancing Oil Recovery" by J. Wang, H. Liu, H. Zhang, G. Zhang, P. Liu and K. Sepehrnoori. The paper describes a model for foam injection and is validated with core flooding experiments both in the absence and in the presence of oil. The important role of the permeability and gas/liquid ratio is highlighted among other parameters (Wang et al., 2015).

"Testing of Snorre Field Foam Assisted Water Alternating Gas (FAWAG) Performance in New Foam Screening Model" by P. Spirov and S. Rudyk. The paper reports a study of foam injection in a norvegian reservoir during 5 years. A model was elaborated and is in good agreement with the results. It is suggested that the model will allow planning water and gas injections in future field studies (Spirov and Rudyk, 2015).

The following group is devoted to asphaltenes.

"Structural Study of Asphaltenes from Iranian Heavy Crude Oil" by L. Davarpanah, F. Vahabzadeh and A. Dermanaki. The authors conducted a study of on Iranian crude oil using different techniques including both FTIR and NMR spectroscopy, as well as SEM examination. In addition to expected results, it appears that the removal of resins from the heavy crude oil generates some disturbance of its colloidal nature whereas asphaltene flocculation and precipitation may occur (Davarpanah et al., 2015).

"Experimental Study and Mathematical Modeling of Asphaltene Deposition Mechanism in Core Samples" by T. Jafari Behbahani, C. Ghotbi, V. Taghikhani and A. Shahrabadi. The purpose of this paper is to use an Iranian bottom-hole oil-sample instead a synthetic mixture to determine the effect of asphaltene deposition on the permeability reduction and porosity reduction of carbonate, sandstone and dolomite rock samples. The experimental data are modeled based on the multilayer adsorption equilibrium mechanism and four material balance equations. The result is in agreement with the experimental data of natural depletion reported in different case-studies (Jafari Behbahani et al., 2015). 
"Prediction of the Gas Injection Effect on the Asphaltene Phase Envelope" by P. Bahrami, R. Kharrat, S. Mahdavi and H. Firoozinia. The authors conducted a broad study to predict the effects of different injected gases on asphaltene onset and to prevent future asphaltene precipitation based on the laboratory data. With temperature reduction, asphaltene precipitation weakened and made the onset pressure decrease for the selected oil. This behavior is different from the results obtained in previous published reports (Bahrami et al., 2015).

Lastly, four articles of the third group treat different aspects of the problem of hydrates.

"Methane Hydrate Formation and Dissociation in the Presence of Silica Sand and Bentonite Clay" by V. Kumar Saw, G. Udayabhanu, A. Mandal and S. Laik. This paper investigates the formation and dissociation of methane hydrates in a synthetic porous media. The authors study the effects of the particle size of silica sand as well as a mixture of bentonite clay and silica sand on the kinetic of methane hydrate formation and dissociation. The phase equilibrium curve of methane hydrate was examined under different experimental conditions (Kumar Saw et al., 2015).

"Prediction of Mass Flow Rate in Supersonic Natural Gas Processing" by C. Wen, X. Cao, Y. Yang and Y. Feng. The authors numerically calculated the mass flow rate of natural gas through a supersonic separator using various equations of state. Their results show that the compressibility factor and specific heat ratio for ideal gas law diverge over $10 \%$ compared to the real gas models at a high inlet pressure (Wen et al., 2015).

"Experimental Study on Hydrate Induction Time of Gas-Saturated Water-in-Oil Emulsion using a High-Pressure Flow Loop" by X.F. Lv, B.H. Shi, Y. Wang, Y.X. Tang, L.Y. Wang and J. Gong. The paper examines the induction time of the natural gas hydrate formation in a flow loop system under various conditions such as the supercooling and supersaturation degree, water cut, anti-agglomerate quantity. It appears that the hydrate induction time decreases first, and then increases with the increasing flow rate in the high-pressure flow loop. Lastly, the authors propose a method for the study of induction time of gas hydrates (Lv et al., 2015).

"Hollow Silica: A Novel Material for Methane Storage" by V.D. Chari, P.S.R. Prasad and S.R. Murthy. This paper compares the methane gas storage as gas hydrate in hollow silica with its storage with solid silica and pure water systems. The effect of stirring on the hydrate formation kinetics and yield is clearly evidenced in the case of solid and pure water systems, whereas it does not show any influence in hollow silica. However, the methane gas conversion into gas hydrate in solid silica and pure water systems is 10 times higher in a stirred reactor when compared with a non-stirred system (Chari et al., 2015).

This collection of articles, published in the present issue of the Oil \& Gas Science and Technology - Revue d'IFP Energies nouvelles, provides many useful contributions for the reader interested by such diverse topics of EOR, gas hydrate stability and influence of asphaltenes in hydrocarbon production.

\section{REFERENCES}

Alomair O., Malallah A., Elsharkawy A., Iqbal M. (2015) Predicting $\mathrm{CO}_{2}$ Minimum Miscibility Pressure (MMP) Using Alternating Conditional Expectation (ACE) Algorithm, Oil Gas Sci. Technol., 70, 6, 967-982.

Bahrami P., Kharrat R., Mahdavi S., Firoozinia H. (2015) Prediction of the Gas Injection Effect on the Asphaltene Phase Envelope, Oil Gas Sci. Technol., 70, 6, 1075-1086.

Chari V.D., Prasad P.S.R., Murthy S.R. (2015) Hollow Silica: A Novel Material for Methane Storage, Oil Gas Sci. Technol., 70, 6, 1125-1132.

Davarpanah L., Vahabzadeh F., Dermanaki A. (2015) Structural Study of Asphaltenes from Iranian Heavy Crude Oil, Oil Gas Sci. Technol., 70, 6, 1035-1049.

Ezeuko C.C., Wang J., Kallos M.S., Gates I.D. (2015) Towards the Development of Bitumen Carbonates: An Integrated Analysis of Grosmont Steam Pilots, Oil Gas Sci. Technol., 70, 6, 983-1005.

Haiyang Y., Yefei W., Jian Z., Peng L., Shenglong S. (2015) Dynamic Gelation of HPAM/Cr(III) under Shear in an Agitator and Porous Media, Oil Gas Sci. Technol., 70, 6, 941-949.

Henaut I., Pasquier D., Rovinetti S., Espagne B. (2015) HP-HT Drilling Mud Based on EnvironmentlyFriendly Fluorinated Chemicals, Oil Gas Sci. Technol., 70, 6, 917-930. 
Jafari Behbahani T., Ghotbi C., Taghikhani V., Shahrabadi A. (2015) Experimental Study and Mathematical Modeling of Asphaltene Deposition Mechanism in Core Samples, Oil Gas Sci. Technol., 70, 6, 1051-1074.

Ju B., Wu Y.-S., Qin J. (2015) Computer Modeling of the Displacement Behavior of Carbon Dioxide in Undersaturated Oil Reservoirs, Oil Gas Sci. Technol., 70, 6, 951-965.

Kumar Saw V., Udayabhanu G., Mandal A., Laik S. (2015) Methane Hydrate Formation and Dissociation in the Presence of Silica Sand and Bentonite Clay, Oil Gas Sci. Technol., 70, 6, 1087-1099.

Langevin D., Combarnous M. (2012) Challenges and new approaches in EOR, Oil Gas Sci. Technol., 67, 6, 883-886.

Lv Y.F., Shi B.H., Wang Y., Tang Y.X., Wang L.Y., Gong J. (2015) Experimental Study on Hydrate Induction Time of Gas-Saturated Water-in-Oil Emulsion using a High-Pressure Flow Loop, Oil Gas Sci. Technol., 70, 6, 1111-1124.

Makogon Y.F. (2010) Natural gas hydrates - A promising source of energy, Journal of Natural Gas Science and Engineering, 2, 1, 49-59, doi: 10.1016/j.jngse.2009.12.004

Speight J.G. (2004) Petroleum asphaltenes - Part 1 - Asphaltenes, resins and the structure of petroleum, Oil Gas Sci. Technol., 59, 5, 467-477

Spirov P., Rudyk S. (2015) Testing of Snorre Field Foam Assisted Water Alternating Gas (FAWAG) Performance in New Foam Screening Model, Oil Gas Sci. Technol., 70, 6, 1025-1033.

Wang J., Liu H., Zhang H., Zhang G., Liu P., Sepehrnoori K. (2015) A Novel Model of Foam Flooding Considering Multi-Factors for Enhancing Oil Recovery, Oil Gas Sci. Technol., 70, 6, 1007-1023.

Wen C., Cao X., Yang Y., Feng Y. (2015) Prediction of Mass Flow Rate in Supersonic Natural Gas Processing, Oil Gas Sci. Technol., 70, 6, 1101-1109.

Zhang P., Wang Y., Yang Y., Chen W., Baie S. (2015) Effective Viscosity in Porous Media and Applicable Limitations for Polymer Flooding of an Associative Polymer, Oil Gas Sci. Technol., 70, 6, 931-939. 


\title{
Éditorial
}

\author{
Dominique Langevin ${ }^{1}$ and François Baudin ${ }^{2}$ \\ 1 Université Paris 11, Laboratoire de Physiques des Solides, UMR 8502, 91405 Orsay - France \\ 2 Université de Paris 06, Institut des Sciences de la Terre de Paris, UMR 7193, 75005 Paris - France
}

Le $6^{\mathrm{e}}$ numéro d'Oil \& Gas Science and Technology - Revue d'IFP Energies nouvelles (OGST) en 2015 recueille des contributions individuelles, à la différence des autres numéros, dédiés à des sujets particuliers ou bien à des recueils de publications issues de conférences organisées à l'IFP Energies nouvelles (IFPEN). Les contributions de ce numéro ont été classées en trois groupes : récupération assistée du pétrole (Enhanced Oil Recovery, EOR), asphaltènes et hydrates. Un numéro spécial en 2012 a été dédié à l'EOR : «Défis et nouvelles approches en EOR ». L'éditorial correspondant décrit la perspective historique en détail (Langevin et Combarnous, 2012). Nous rappellerons simplement ici que, après une période très active suivant le choc pétrolier de 1973 et une période moins intense autour de 2000 lorsque le prix du pétrole a chuté, une recherche active a repris ces dernières années. Les huiles lourdes et les bitumes constituant une fraction importante des réserves actuelles, une partie des nouvelles recherches est consacrée aux problèmes spécifiques posés par ces bruts très visqueux.

Les asphaltènes ont également fait l'objet de recherches intensives depuis de nombreuses années (Speight, 2004). Ce sont les composants des bruts de polarité et de poids moléculaire les plus élevés. Si le brut contient des quantités appréciables de composants légers non polaires, les asphaltènes peuvent précipiter et causer des dommages. Lorsque la quantité d'asphaltènes est élevée, le brut est très visqueux, conduisant à des problèmes d'extraction et de transport. Les asphaltènes étant plus polaires que les autres composants du brut, ils ont tendance à adsorber sur les surfaces, un sujet également beaucoup étudié en lien avec la mouillabilité de la roche réservoir et la stabilité des émulsions formées en présence d'eau. Malgré des années de recherche, nos connaissances sur les asphaltènes sont encore limitées. Une des difficultés vient du fait que les asphaltènes sont des mélanges de nombreuses espèces différentes, qui diffèrent suivant la méthode d'extraction du brut employée. Les asphaltènes ont par ailleurs tendance à s'agréger, rendant la simple détermination de leur poids moléculaire difficile. De nombreuses controverses sur le comportement des asphaltènes ont eu lieu au fil des années, certaines sont toujours très actives.

Les hydrates de gaz sont des substances semblables à de la glace, dans lesquelles les molécules gazeuses sont piégées dans une cage de molécules d'eau liées par des liaisons hydrogène. Ils se forment naturellement lorsque la température est basse et la pression élevée. De telles conditions existent dans les séries sédimentaires des marges continentales, dans le permafrost, certains puits pétroliers et dans les pipelines. Leur mode de formation et de décomposition à l'échelle moléculaire, qui correspond toutefois à des changements de phase et non à des réactions chimiques, n'est pas encore bien compris. La recherche sur les hydrates est 
actuellement très active et vise à optimiser leur extraction et à mieux prédire les accidents potentiels (Makogon, 2010).

Nous allons maintenant présenter brièvement le contenu des différents articles de ce numéro, en commençant par ceux dédiés à l'EOR.

«Boues de forage HP-HT à base de composés fluorés respectueux de l'environnement » par I. Hénaut, D. Pasquier, S. Rovinetti et B. Espagne. Ce papier décrit de nouvelles formulations de boues de forage à base de composés perfluorés, capables de fonctionner à haute température et haute pression (Henaut et al., 2015).

«Viscosité effective dans des médias poreux et limites d'application de l'injection de polymères associatifs » par P. Zhang, Y. Wang, Y. Yang, W. Chen et S. Bai. Dans ce papier, la supériorité de l'effet viscosifiant d'un polyacrylamide modifié hydrophobe par rapport au polyacrylamide non modifié est démontrée. L'efficacité des deux types de polymères au cours du déplacement d'huile en milieux poreux est également comparée. Les auteurs proposent le polymère modifié comme candidat intéressant en EOR (Zhang et al., 2015).

« Gélification dynamique de HPAM/Cr(III) sous cisaillement dans un agitateur et en milieux poreux » par Y. Haiyang, W. Yefei, Z. Jian, L. Peng et S. Shenglong. Cet article étudie la gélification d'un polymère standard utilisé en EOR pour augmenter la viscosité de l'eau. Les expériences faites en bouteille et en milieu poreux ont été comparées à la fois au repos et sous écoulement. Les temps de gélification ont été trouvés beaucoup plus longs en milieu poreux (Haiyang et al., 2015).

«Modélisation par ordinateur du comportement de déplacement du dioxyde de carbone dans des réservoirs d'huile non saturés » par B. Ju, Y.-S. Wu et J. Qin. Ce nouveau modèle permet la prédiction du flux de $\mathrm{CO}_{2}$ dans des réservoirs de pétrole, en situation miscible et non miscible. Le modèle a été validé avec des données expérimentales (Ju et al., 2015).

«Prédiction de la pression miscibilité minimum (MMP) du $\mathrm{CO}_{2}$ en utilisant un algorithme basé sur l'ACE (Alternating Conditional Expectation) » par O. Alomair, A. Malallah, A. Elsharkawy et M. Iqbal. Ce nouveau modèle permet de retrouver la pression de miscibilité minimum de $\mathrm{CO}_{2}$ pur mesurée avec plus de 100 huiles différentes. Le modèle n'a pas de paramètres ajustables et se base uniquement sur des données expérimentales (Alomair et al., 2015).

«Vers le développement des carbonates bitumineux : une analyse intégrée des pilotes vapeur de Grosmont » par C.C. Ezeuko, J. Wang, M.S. Kallos et I.D. Gates. Ce papier modélise des essais d'injection de vapeur dans des pilotes installés dans des carbonates bitumineux au Canada. Une méthode particulière (simulation de vapeur cyclique) est recommandée pour exploiter ce réservoir (Ezeuko et al., 2015).

«Un nouveau modèle d'injection de mousse considérant de multiples facteurs afin d'améliorer la récupération de pétrole » par J. Wang, H. Liu, H. Zhang, G. Zhang, P. Liu et K. Sepehrnoori. Le papier décrit un modèle pour l'injection de mousse, qui est validé par des expériences à la fois en l'absence et en présence d'huile. Le rôle important de la perméabilité et du rapport gaz/liquide est mis en évidence, parmi d'autres paramètres (Wang et al., 2015).

"Vérification des performances de la méthode FAWAG (Foam Assisted Water Alternating Gas) sur le champ de Snorre, en Norvège, avec un nouveau modèle de sélection des mousses » par P. Spirov et S. Rudyk. Le papier décrit une étude d'injection de mousse dans un réservoir norvégien pendant 5 ans. Un modèle a été élaboré et est en bon accord avec les résultats. Il est suggéré que le modèle permettra de planifier les injections d'eau et de gaz dans les futures études sur le terrain (Spirov et Rudyk, 2015).

Le groupe suivant est dédié aux asphaltènes.

«Étude structurale des asphaltènes d'un pétrole brut lourd iranien » par L. Davarpanah, F. Vahabzadeh et A. Dermanaki. Les auteurs ont mené une étude sur une huile lourde d'Iran en utilisant différentes techniques, dont la spectroscopie IRTF et RMN, ainsi que des observations au MEB. En plus des résultats attendus, il apparaît que le retrait de la fraction résine du pétrole brut perturbe la nature colloïdale du fluide, la floculation et la précipitation des asphaltènes finissant par se produire (Davarpanah et al., 2015). 
"Étude expérimentale et modélisation mathématique du mécanisme de déposition d'asphaltènes dans des carottes de forage " par T. Jafari Behbahani, C. Ghotbi, V. Taghikhani et A. Shahrabadi. Le propos de cet article est d'utiliser un échantillon d'huile de fond de puits plutôt qu'un échantillon synthétique afin de déterminer les effets du dépôt d'asphaltènes sur la diminution de perméabilité et la réduction de la porosité d'échantillons de carbonates, grès et dolomites. Les données expérimentales sont modélisées sur la base de mécanisme d'absorption à l'équilibre multicouches et quatre équations de bilan de matière. Les résultats sont en accord avec les données expérimentales d'épuisement naturel présentées dans différents cas d'étude (Jafari Behbahani et al., 2015).

«Prévision de l'effet d'injection de gaz sur l'enveloppe de phase des asphaltènes " par P. Bahrami, R. Kharrat, S. Mahdavi et H. Firoozinia. En se fondant sur des études de laboratoire, les auteurs ont conduit une vaste étude pour prédire les effets de différents gaz injectés lors de l'initiation de la précipitation des asphaltènes et pour prévenir toute précipitation ultérieure. Dans le cas de l'huile sélectionnée pour cette étude, la diminution de température entraine une moindre précipitation des asphaltènes et une chute de la pression de départ. Ce comportement est assez différent des résultats des études antérieures (Bahrami et al., 2015).

Enfin, les quatre articles du troisième groupe traitent différents aspects du problème des hydrates.

«Formation et dissociation d'hydrates de méthane en présence de sable de silice et d'argile de bentonite » par V. Kumar Saw, G. Udayabhanu, A. Mandal et S. Laik. Cet article examine la formation et la dissociation d'hydrates de méthane dans un milieu poreux synthétique. Les auteurs étudient les effets de la taille des particules de silice ainsi que le mélange sable de silice et bentonite sur la cinétique de la formation et de la dissociation des hydrates. Les courbes d'équilibre de phase sont examinées dans différentes conditions expérimentales (Kumar Saw et al., 2015).

"Prédiction du débit massique dans les applications de traitement supersonique du gaz naturel » par C. Wen, X. Cao, Y. Yang et Y. Feng. En utilisant plusieurs équations d'état, les auteurs calculent le débit massique volumique d'un gaz naturel à travers un séparateur supersonique. Ils montrent ainsi que le facteur de compressibilité et les coefficients de chaleur spécifique calculés avec les modèles de gaz parfaits diffèrent d'au moins $10 \%$ des résultats obtenus avec une pression d'injection élevée (Wen et al., 2015).

«Etude expérimentale sur le temps d'induction d'hydrate d'une émulsion eau-en-huile saturée en gaz en utilisant une boucle à circulation sous haute pression » par X.F. Lv, B.H. Shi, Y. Wang, Y.X. Tang, L.Y. Wang et J. Gong. Ce papier examine le temps d'induction des hydrates dans différentes conditions comme le degré de sur-réfrigération et de sursaturation, le watercut, le dosage d'anti-agglomérants. Il apparaît que le temps d'induction diminue tout d'abord avant d'augmenter lorsque l'on augmente le flux dans la boucle de circulation. Une méthode pour l'analyse du temps d'induction est finalement proposée (Lv et al., 2015).

"La silice creuse : un nouveau matériau pour le stockage de méthane " par V.D. Chari, P.S.R. Prasad et S.R. Murthy. Ce papier compare le stockage de méthane sous forme d'hydrate avec de la silice creuse et avec une silice normale en présence d'eau. L'effet de l'agitation sur la cinétique de formation des hydrates et le rendement est mis en évidence pour la silice normale en présence d'eau, tandis qu'aucune influence n'est détectée dans le cas de la silice creuse. La conversion du méthane en hydrate s'avère dix fois plus rapide dans un réacteur agité plutôt que non-agité (Chari et al., 2015).

Cette série d'articles, publiés dans le présent numéro de Oil \& Gas Science and TechnologyRevue d'IFP Energies nouvelles, offre un ensemble de contributions utiles au lecteur intéressé par la diversité des approches sur la récupération assistée des pétroles, la stabilité des hydrates de gaz et l'influence des asphaltènes dans la production des hydrocarbures. 


\section{RÉFÉRENCES}

Alomair O., Malallah A., Elsharkawy A., Iqbal M. (2015) Predicting $\mathrm{CO}_{2}$ Minimum Miscibility Pressure (MMP) Using Alternating Conditional Expectation (ACE) Algorithm, Oil Gas Sci. Technol., 70, 6, 967-982.

Bahrami P., Kharrat R., Mahdavi S., Firoozinia H. (2015) Prediction of the Gas Injection Effect on the Asphaltene Phase Envelope, Oil Gas Sci. Technol., 70, 6, 1075-1086.

Chari V.D., Prasad P.S.R., Murthy S.R. (2015) Hollow Silica: A Novel Material for Methane Storage, Oil Gas Sci. Technol., 70, 6, 1125-1132.

Davarpanah L., Vahabzadeh F., Dermanaki A. (2015) Structural Study of Asphaltenes from Iranian Heavy Crude Oil, Oil Gas Sci. Technol., 70, 6, 1035-1049.

Ezeuko C.C., Wang J., Kallos M.S., Gates I.D. (2015) Towards the Development of Bitumen Carbonates: An Integrated Analysis of Grosmont Steam Pilots, Oil Gas Sci. Technol., 70, 6, 983-1005.

Haiyang Y., Yefei W., Jian Z., Peng L., Shenglong S. (2015) Dynamic Gelation of HPAM/Cr(III) under Shear in an Agitator and Porous Media, Oil Gas Sci. Technol., 70, 6, 941-949.

Henaut I., Pasquier D., Rovinetti S., Espagne B. (2015) HP-HT Drilling Mud Based on EnvironmentlyFriendly Fluorinated Chemicals, Oil Gas Sci. Technol., 70, 6, 917-930.

Jafari Behbahani T., Ghotbi C., Taghikhani V., Shahrabadi A. (2015) Experimental Study and Mathematical Modeling of Asphaltene Deposition Mechanism in Core Samples, Oil Gas Sci. Technol., 70, 6, 1051-1074.

Ju B., Wu Y.-S., Qin J. (2015) Computer Modeling of the Displacement Behavior of Carbon Dioxide in Undersaturated Oil Reservoirs, Oil Gas Sci. Technol., 70, 6, 951-965.

Kumar Saw V., Udayabhanu G., Mandal A., Laik S. (2015) Methane Hydrate Formation and Dissociation in the Presence of Silica Sand and Bentonite Clay, Oil Gas Sci. Technol., 70, 6, 1087-1099.

Langevin D., Combarnous M. (2012) Challenges and new approaches in EOR, Oil Gas Sci. Technol., 67, 6, 883-886.

Lv Y.F., Shi B.H., Wang Y., Tang Y.X., Wang L.Y., Gong J. (2015) Experimental Study on Hydrate Induction Time of Gas-Saturated Water-in-Oil Emulsion using a High-Pressure Flow Loop, Oil Gas Sci. Technol., 70, 6, 1111-1124.

Makogon Y.F. (2010) Natural gas hydrates - A promising source of energy, Journal of Natural Gas Science and Engineering, 2, 1, 49-59. doi: 10.1016/j.jngse.2009.12.004

Speight J.G. (2004) Petroleum asphaltenes - Part 1 - Asphaltenes, resins and the structure of petroleum, Oil Gas Sci. Technol., 59, 5, 467-477

Spirov P., Rudyk S. (2015) Testing of Snorre Field Foam Assisted Water Alternating Gas (FAWAG) Performance in New Foam Screening Model, Oil Gas Sci. Technol., 70, 6, 1025-1033.

Wang J., Liu H., Zhang H., Zhang G., Liu P., Sepehrnoori K. (2015) A Novel Model of Foam Flooding Considering Multi-Factors for Enhancing Oil Recovery, Oil Gas Sci. Technol., 70, 6, 1007-1023.

Wen C., Cao X., Yang Y., Feng Y. (2015) Prediction of Mass Flow Rate in Supersonic Natural Gas Processing, Oil Gas Sci. Technol., 70, 6, 1101-1109.

Zhang P., Wang Y., Yang Y., Chen W., Baie S. (2015) Effective Viscosity in Porous Media and Applicable Limitations for Polymer Flooding of an Associative Polymer, Oil Gas Sci. Technol., 70, 6, 931-939. 